\section{Pacific Northwest}

National Laboratory

Operated by Battelle for the

U.S. Department of Energy

\title{
Archaeological Excavation Report for Proposed Well 199-K-131 in Support of the 100-KR-4 Pump- and-Treat Project
}

\author{
D. M. Woody \\ E. L. Prendergast-Kennedy
}

June 2004

Prepared for the U.S. Department of Energy under Contract DE-AC06-76RL01830 


\title{
DISCLAIMER
}

This report was prepared as an account of work sponsored by an agency of the United States Government. Neither the United States Government nor any agency thereof, nor Battelle Memorial Institute, nor any of their employees, makes any warranty, express or implied, or assumes any legal liability or responsibility for the accuracy, completeness, or usefulness of any information, apparatus, product, or process disclosed, or represents that its use would not infringe privately owned rights. Reference herein to any specific commercial product, process, or service by trade name, trademark, manufacturer, or otherwise does not necessarily constitute or imply its endorsement, recommendation, or favoring by the United States Government or any agency thereof, or Battelle Memorial Institute. The views and opinions of authors expressed herein do not necessarily state or reflect those of the United States Government or any agency thereof.

\author{
PACIFIC NORTHWEST NATIONAL LABORATORY \\ operated by \\ BATTELLE \\ for the \\ UNITED STATES DEPARTMENT OF ENERGY \\ under Contract DE-AC06-76RL01830
}

Printed in the United States of America
Available to DOE and DOE contractors from the Office of Scientific and Technical Information,
P.O. Box 62, Oak Ridge, TN 37831-0062;
ph: (865) 576-8401
fax: (865) 576-5728
email: reports@adonis.osti.gov

\author{
Available to the public from the National Technical Information Service, \\ U.S. Department of Commerce, 5285 Port Royal Rd., Springfield, VA 22161 \\ ph: (800) 553-6847 \\ fax: (703) 605-6900 \\ email: orders@ntis.fedworld.gov \\ online ordering: http://www.ntis.gov/ordering.htm
}

This document was printed on recycled paper. 


\title{
Archaeological Excavation Report for Proposed Well 199-K-131 in Support of the 100-KR-4 Pump- and-Treat Project
}

\author{
D. M. Woody \\ E. L. Prendergast-Kennedy
}

June 2004

Prepared for

the U.S. Department of Energy

under Contract DE-AC06-76RL01830

Pacific Northwest National Laboratory

Richland, Washington 99352 


\section{Contents}

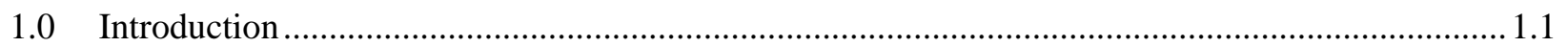

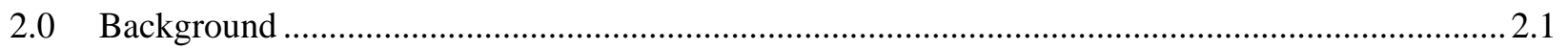

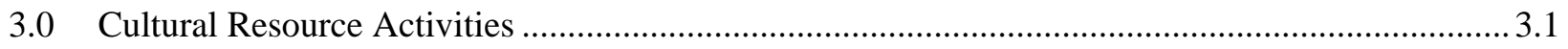

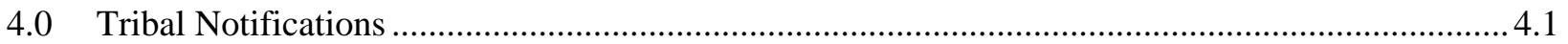

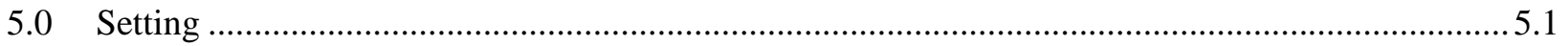

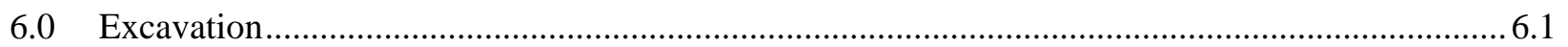

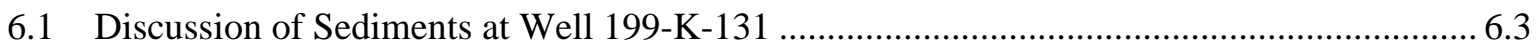

6.2 Discussion of Cultural Materials Observed at Well 199-K-131........................................... 6.5

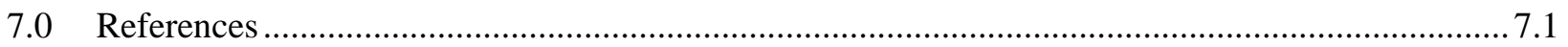




\section{Figures}

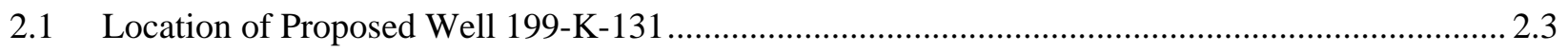

5.1 Aerial Photograph Taken in May 2002 Showing the Location of Proposed Well 199-K-131 ........ 5.1

6.1 Photograph Showing the Cultural Materials Recovered From Level 5 of the Test Unit................. 6.2

6.2 Profile of the North Wall of the 199-K-131 Excavation Unit...................................................... 6.3

6.3 Photograph Showing the North Wall of the Excavation Unit...................................................... 6.4 


\subsection{Introduction}

An archaeological excavation was conducted at the site of proposed groundwater monitoring well 199-K-131 in support of the 100-KR-4 Pump-and-Treat Project between June 2 and 3, 2004. Excavations confirmed that there were no intact cultural deposits at the proposed well location. This report was prepared to document the findings of the test excavation. 


\subsection{Background}

The 100-KR-4 Pump-and-Treat Project is located between the 100-K and 100-N Areas of the Hanford Site between the shoreline of the Columbia River, and the "mile-long trench." The mile-long trench was conceived and constructed as a facility which would receive contaminated discharged cooling water and chromium derived from reactor operations (DOE-RL 1992). The chromium contaminated water discharged into the trench was eventually determined to have leached into the soil and groundwater.

As a means of reducing the amount of chromium reaching the Columbia River through groundwater transport, the 100-KR-4 Pump-and-Treat Project was created in 1996. The 100-KR-4 Pump-and-Treat Project consists of a pump-and-treat facility, several extraction wells located along the lower terrace of the Columbia River, several injection wells placed along the upper terrace, and groundwater monitoring wells dispersed along both terraces.

A cultural resources review (HCRC\# 96-100-013) was completed for the 100-KR-4 Pump-and-Treat Project by Marceau and Woodruff (1996). The cultural resources review required an archaeological survey of the 100-K Terrace because the project is located in an area known to be culturally sensitive due to its historical and spiritual significance to the Wanapum people and other tribes. The 100-K Terrace is near a Wanapum winter village which is associated with the activities of Smohalla, a Wanapum spiritual leader, and Mooli Mooli, an area with traditional significance to the Wanapum. It is also known to be an important resource gathering area for dog salmon (Relander 1986). These areas have been placed in two archaeological districts: the Coyote Rapids Archaeological District, which was listed on the Washington State Register in 1975; and the Ryegrass Archaeological District, which was listed on the National Register of Historic Places (National Register) in 1976.

This survey was completed in February 1996. No new cultural resources were recorded, but concentrations of cultural material associated with the previously recorded sites were rerecorded. As a result of that survey, a Cultural Resources Sensitivities Map was developed dividing the area into areas of categories of Disturbed, High Potential, Extremely High Potential, and Off Limits.

To minimize ongoing project impacts to the cultural resources in the area, a treatment plan was developed in consultation with affected tribes (DOE-RL 1996). Using the Cultural Resources Sensitivities Map, the initial project design was substantially altered. All proposed ground-disturbing facilities from the historic Wanapum Cemetery were removed from the design, while other planned facilities were relocated outside other areas of extreme high sensitivity whenever possible. The treatment plan prescribed specific measures to be taken to avoid or minimize impacts to known cultural resources before, during, and after construction, as well as during continued operations. Pursuant to the treatment plan, archaeological test excavations would be required in areas designated for drilling to minimize impacts to suspected, but undocumented, subsurface cultural resources. Specifically, the treatment plan states:

"With the assistance of tribal representatives, test pits ( $1 \mathrm{~m}$ by $1 \mathrm{~m}$ [3.3 by $3.3 \mathrm{ft}$ ]) will be hand excavated by cultural resources specialists to determine the presence or absence of subsurface cultural deposits at the new well location. Excavation will be confined to fine sediments; 
excavations will terminate when cobble strata are encountered. If [National] Register-eligible artifacts or museum quality items are found, (e.g., temporal diagnostics, Euro-American trade ware), consultations with affected Tribes will be held to determine the appropriated disposition of these items. If no cultural materials are discovered or if the contents of the pits consist only on isolated artifacts (e.g., lithic flakes, shell fragments, fragmented animal bone, fire cracked rock) found in unconsolidated sands, these materials will be recorded through limited field analysis (e.g., quantity, lithic type, sized, reduction sequence) and returned to the pit in a location that will not be impacted by drilling. The pit will then be backfilled and [an] above ground marker will be placed to show the pit location. Drilling may begin at the location of the marker.

If cultural features (e.g., house pits, fires hearths, living floors) are encountered in the test pit, excavation will terminate and these features will be left in place. Limited field analysis and documentation of the finds will be conducted. This will include photography, written descriptions, and mapping. The pit will then be backfilled and no further activities will take place in this test pit. A new location within the area selected for well drilling will be tested.

Discoveries made after three consecutive attempts to find a suitable location will require that the U.S. Department of Energy (DOE) and project engineers make a decision. Alternatives may include, but are not limited to the following: continue testing within designation area, accept the impact to the cultural resource (excavate and record), or relocate the well pad.

If human remains or funerary objects are discovered in the test pit, the area will be stabilized (i.e., covered and secured) and will not be used for well drilling. Tribal representatives will be notified in accordance with NAGPRA procedures and they will determine the appropriate disposition of these remains.”

The new well (199-K-131) is located within 139 meters of the Columbia River shoreline (Figure 2.1). The Ryegrass Archaeological District is located 800 meters southwest of the proposed well location, which was listed on the National Register in 1976. A Wanapum winter village site associated with Smoholla is located 1 kilometer southwest of the proposed well location. The lower edge of Mooli Mooli, an area with traditional significance to the Wanapum, lies 1.5 kilometers west of the proposed well location. A house pit site (45BN149) is located on the lower terrace below the proposed well location. 


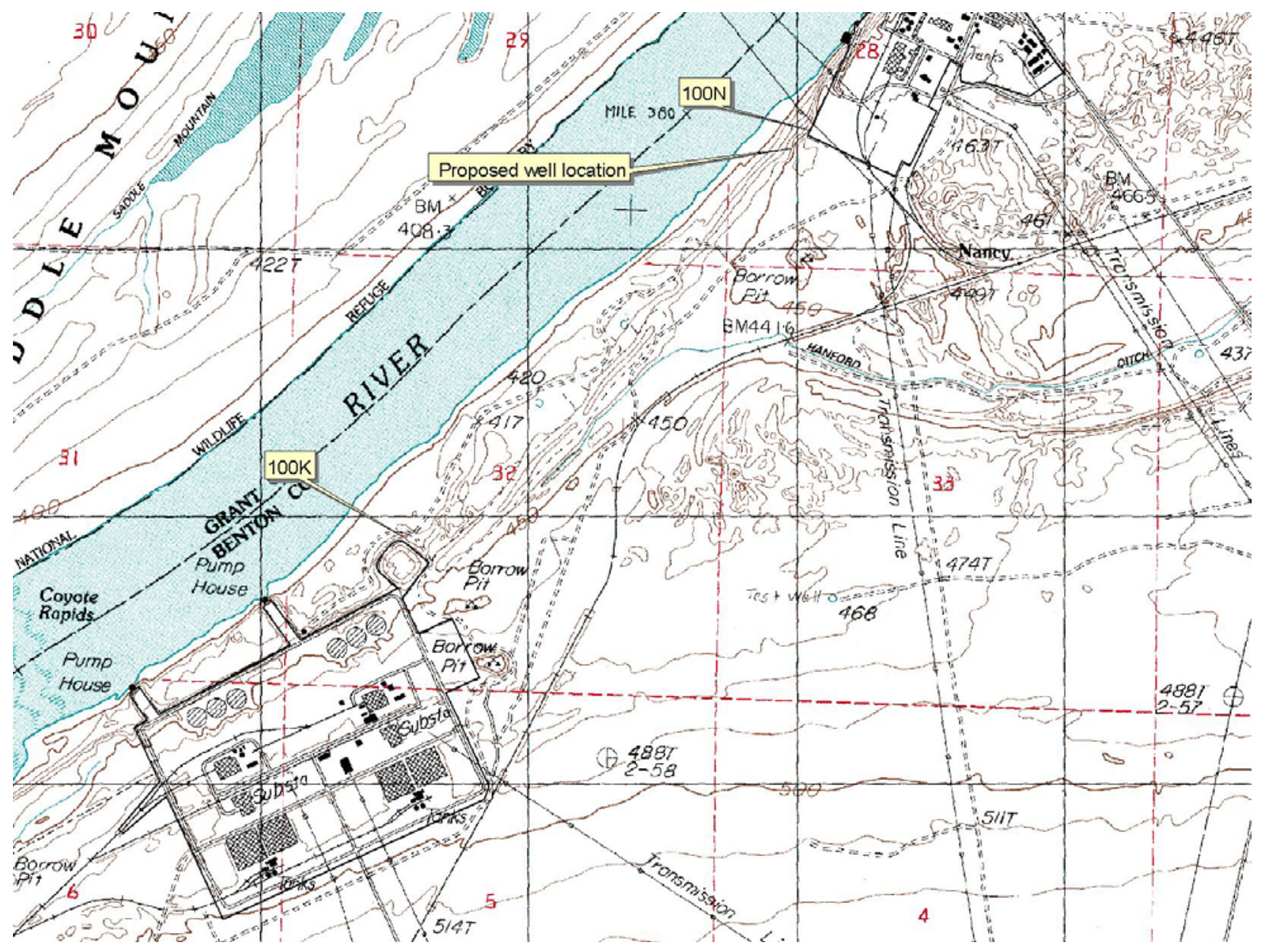

Figure 2.1. Location of Proposed Well 199-K-131 


\subsection{Cultural Resource Activities}

The Hanford Cultural Resources Project (HCRP) assigned project number HCRC \# 2004-100-010 to this activity for tracking purposes. An archaeological test excavation was conducted at the location of monitoring well 199-K-131 between June 2 and 3, 2004, in accordance with the cultural resource treatment plan (DOE-RL 1996). An additional stipulation was added for the archaeological excavation indicating that if cobbles were not encountered before 1.2 meters (the depth requiring shoring or expansion by DOE excavation permit requirements), an auger would used so as not to cause further disturbance in the area. Using archaeological data generated by previous 100-KR-4 Pump-and-Treat Project test excavations, it was determined that the possibility of encountering subsurface cultural materials was very low at the selected location of monitoring well 199-K-131. 


\subsection{Tribal Notifications}

On March 17, 2004, project activities were presented at a Hanford Cultural and Historical Resources Program Tribal Issues Meeting. Cultural resources staff representing the Confederated Tribes and Bands of the Yakama Nation, Confederated Tribes of the Umatilla Reservation, the Nez Perce, and the Wanapum were present at this meeting. On April 12, 2004, a notification of “Area of Potential Effect,” a literature review, and a proposed path forward was sent to cultural resources staff of the Confederated Tribes and Bands of the Yakama Nation, Confederated Tribes of the Umatilla Reservation, the Nez Perce, the Wanapum, the Confederated Tribes of the Colville Reservation, and to the U.S. Department of Energy, Richland Operations Office (DOE-RL) Indian Nations Program. An invitation to participate in the excavation was also sent to the same tribes on May 20, 2004. 


\subsection{Setting}

Two dominant landforms are found in the 100-KR-4 Pump-and-Treat Project area: an upper fluvialdeposited terrace consisting of gravels, cobbles, and boulders; and a lower terrace which lies adjacent to the Columbia River. Previous archaeological excavations show the lower terrace to consist primarily of fluvial and aeolian fine sands and silt.

The proposed monitoring well 199-K-131 is located near the top of the upper terrace overlooking the Columbia River. This terrace is thought to date between 8,000-10,000 years B.P., and consists primarily of fluvial deposited gravels, cobbles, and boulders, as well as aeolian sediments (Marceau and Sharpe 2001). Field observations and aerial photographs show the area of the well to be significantly impacted, possibly by construction or cleanup activities at N Reactor. Aerial photographs of the well location taken in 2002 show the overall disturbance of the general and specific area of the well location, its placement being adjacent to a two-track dirt road and in the vicinity of several excavation areas or borrow pits (Figure 5.1). As recently as June 2004, the well location and the surrounding area have been covered with cobble, gravel, and sand-fill material. Based on the excavation at the location of 199-K-131, this material extends 0.7 meters in depth.

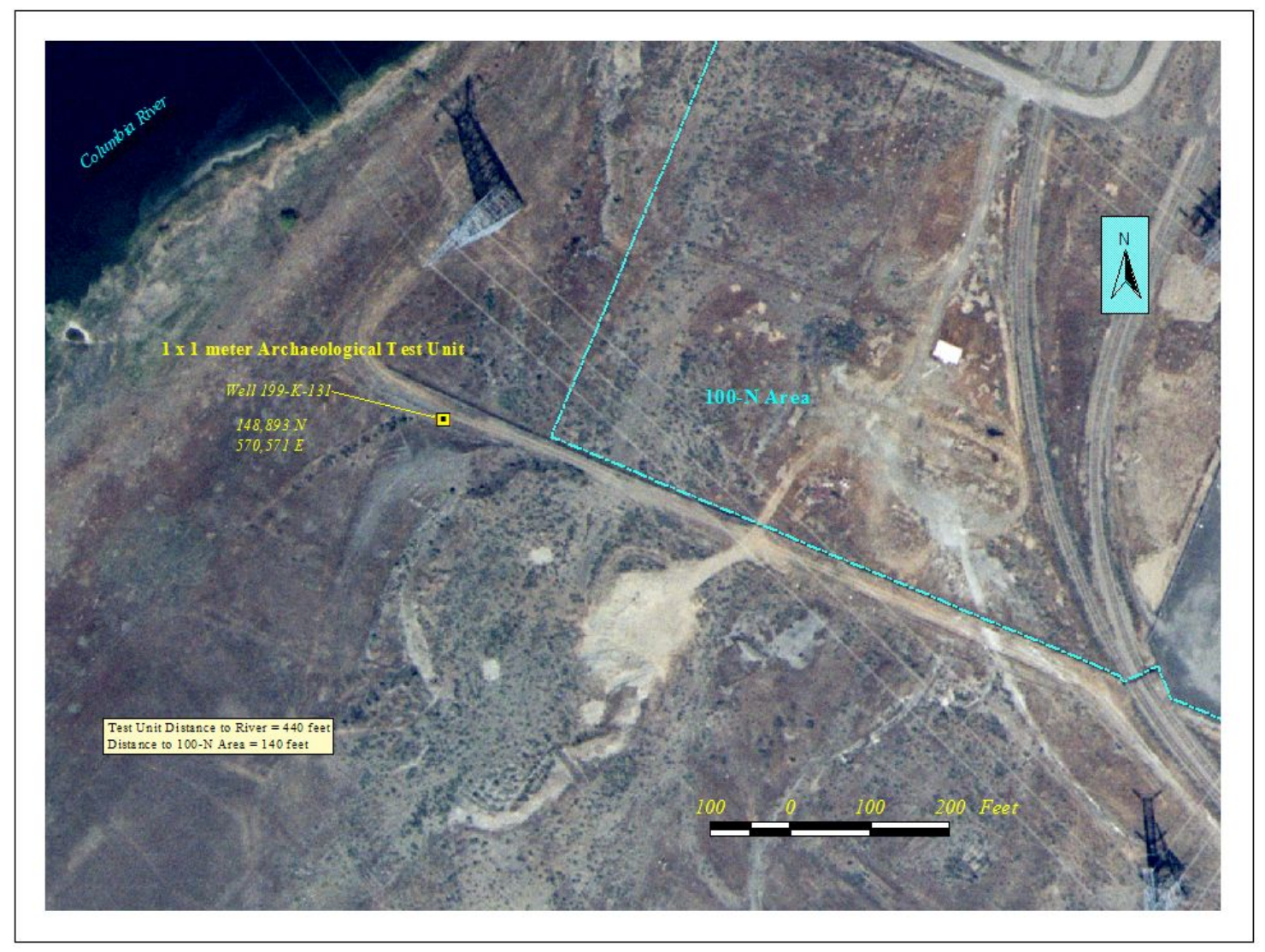

Figure 5.1. Aerial Photograph Taken in May 2002 Showing the Location of Proposed Well 199-K-131 


\subsection{Excavation}

An archaeological test excavation at the proposed well site was conducted between June 2 and 3, 2004. Using the North American Datum (NAD) 1983 Washington South coordinate system, the UTM location is 148, 893 meters northing and 570, 571 meters easting. The test excavation consisted of a 1-meter by 1-meter excavation unit using the previously placed well location flag as the unit nadir, and then oriented to true north. Excavation was done using 10-centimeter arbitrary levels, measuring elevation from a unit datum placed 10 centimeters above the ground surface in the highest corner (southwest corner) of the unit. Sediments from each level were screened though a 0.3175-centimeter wire mesh screen. Findings by level for the excavation unit are as follows:

\begin{tabular}{|c|c|c|c|}
\hline Level & $\begin{array}{l}\text { Depth Below } \\
\text { Datum (cm) }\end{array}$ & Soil Description & Cultural Material Findings \\
\hline 1 & $\begin{array}{l}8 \text { to } 20 \mathrm{~cm} \text { below } \\
\text { unit datum }\end{array}$ & $\begin{array}{l}\text { Cobble, gravel, and sand fill material. } \\
\text { Numerous fragments of concrete were } \\
\text { observed. }\end{array}$ & No cultural materials encountered \\
\hline 2 & $\begin{array}{l}20 \text { to } 30 \mathrm{~cm} \text { below } \\
\text { unit datum }\end{array}$ & $\begin{array}{l}\text { Cobble, gravel, and sand fill material. } \\
\text { Numerous fragments of concrete were } \\
\text { observed. }\end{array}$ & No cultural materials encountered \\
\hline 3 & $\begin{array}{l}30 \text { to } 40 \mathrm{~cm} \text { below } \\
\text { unit datum }\end{array}$ & Cobble, gravel, and sand fill material & No cultural materials encountered \\
\hline 4 & $\begin{array}{l}40 \text { to } 50 \mathrm{~cm} \text { below } \\
\text { unit datum }\end{array}$ & Cobble, gravel, and sand fill material & No cultural materials encountered \\
\hline 5 & $\begin{array}{l}50 \text { to } 60 \mathrm{~cm} \text { below } \\
\text { unit datum }\end{array}$ & Cobble, gravel, and sand fill material & $\begin{array}{l}\text { One cryptocrystalline flake, one possible } \\
\text { basalt flake, and one wire nail were } \\
\text { encountered in this level. Three small } \\
(<0.25 \mathrm{~cm} \text { in size) wood fragments were } \\
\text { also observed, but they are likely not cultural } \\
\text { remains (see Figure } 6.1 \text { for photo of these } \\
\text { materials). }\end{array}$ \\
\hline 6 & $\begin{array}{l}60 \text { to } 70 \mathrm{~cm} \text { below } \\
\text { unit datum }\end{array}$ & $\begin{array}{l}\text { Cobble, gravel, and sand trending } \\
\text { towards a lesser amount of cobble and } \\
\text { an increasing amount of loamy silt near } \\
\text { the base of the level. }\end{array}$ & No cultural materials encountered \\
\hline 7 & $\begin{array}{l}70 \text { to } 80 \mathrm{~cm} \text { below } \\
\text { unit datum }\end{array}$ & $\begin{array}{l}\text { Fine sands, silts, and gravel. This level } \\
\text { is much different than previous levels } \\
\text { with its lack of cobbles. The moisture } \\
\text { content is significantly higher that in } \\
\text { previous levels. }\end{array}$ & No cultural materials encountered \\
\hline 8 & $\begin{array}{l}80 \text { to } 90 \mathrm{~cm} \text { below } \\
\text { datum }\end{array}$ & $\begin{array}{l}\text { Fine sands, silts, gravels and a lesser } \\
\text { amount of cobbles. The cobble and } \\
\text { gravels comprise approximately 40\%- } \\
50 \% \text { of the level. }\end{array}$ & No cultural materials encountered \\
\hline
\end{tabular}




\begin{tabular}{|c|l|l|l||}
\hline \hline 9 & $\begin{array}{l}90 \text { to } 100 \mathrm{~cm} \\
\text { below datum }\end{array}$ & $\begin{array}{l}\text { Fine sands, silts, gravels and a lesser } \\
\text { amount of cobbles. The gravels } \\
\text { comprise approximately 40\%-50\% of } \\
\text { the level. Few cobbles were } \\
\text { encountered. }\end{array}$ & No cultural materials encountered \\
\hline 10 & $\begin{array}{l}100 \text { to } 110 \mathrm{~cm} \\
\text { below datum }\end{array}$ & $\begin{array}{l}\text { Fine sands, silts, and a large percentage } \\
\text { of gravels. The gravels comprise } \\
\text { approximately 70\%-80\% of the level. }\end{array}$ & No cultural materials encountered \\
\hline 11 & $\begin{array}{l}110 \text { to } 120 \mathrm{~cm} \\
\text { below datum }\end{array}$ & $\begin{array}{l}\text { Fine sands, silts, and a large percentage } \\
\text { of gravels. The gravels comprise } \\
\text { approximately 70\%-80\% of the level. }\end{array}$ & No cultural materials encountered \\
\hline 12 & $\begin{array}{l}120 \text { to } 130 \mathrm{~cm} \\
\text { below datum }\end{array}$ & $\begin{array}{l}\text { Fine sands, silts, and a large percentage } \\
\text { of gravels. The gravels comprise } \\
\text { approximately 70\%-80\% of the level. }\end{array}$ & No cultural materials encountered \\
\hline 13 & $\begin{array}{l}130-140 \mathrm{~cm} \text { below } \\
\text { datum }\end{array}$ & $\begin{array}{l}\text { Fine sands, silts, a large percentage of } \\
\text { gravels, and occasional cobble. The } \\
\text { gravels comprise approximately 80\% of } \\
\text { the level. }\end{array}$ & No cultural materials encountered \\
\hline $\begin{array}{l}\text { Although the cultural resource treatment plan calls for excavation to proceed until cobble is reached, or three } \\
\text { successive culturally sterile layers are encountered, excavation was taken to the maximum depth below surface } \\
\text { allowed by DOE excavation safety standards which call for excavation wall support at depths greater than }\end{array}$ \\
$\begin{array}{l}\text { approximately } 120 \text { centimeters below ground surface. This was done in an effort to reach intact sediments rather } \\
\text { than the cobble and gravel fill which extended to the lowest depths of the excavation unit. } \\
\text { cm= centimeters. }\end{array}$
\end{tabular}

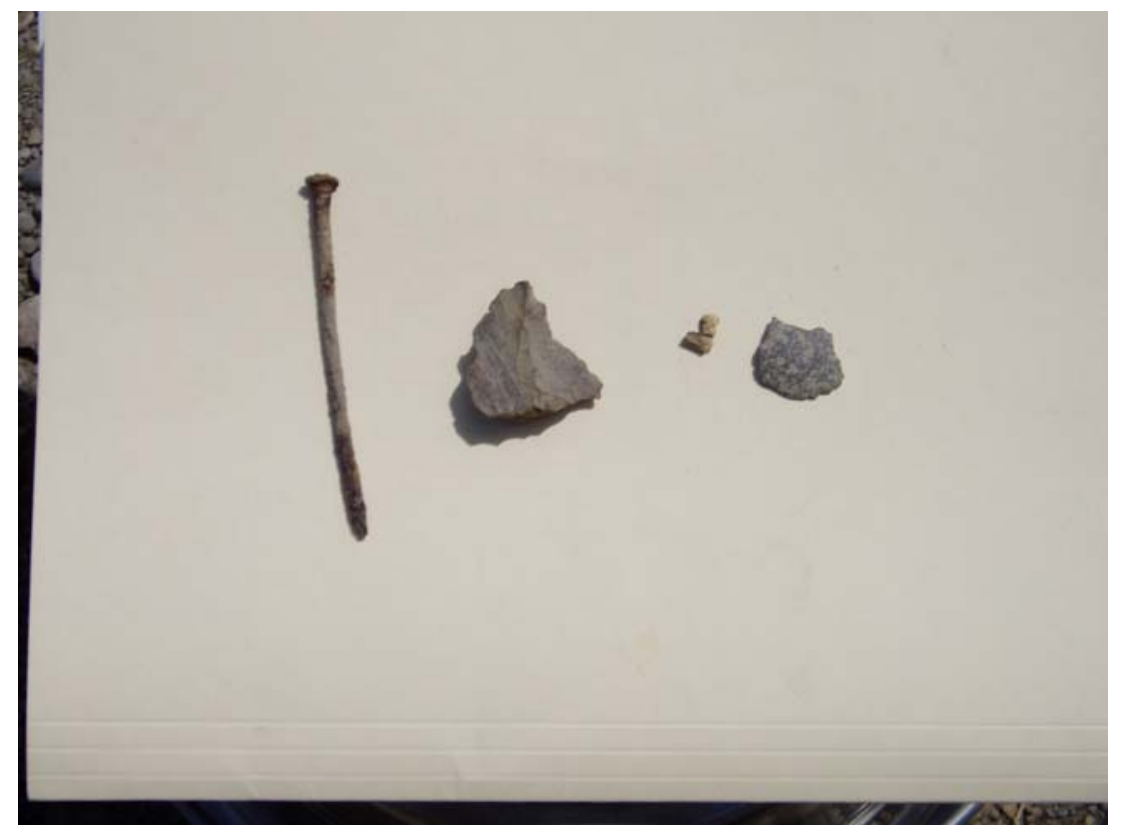

Figure 6.1. Photograph Showing the Cultural Materials Recovered From Level 5 of the Test Unit. Materials from left are: a wire nail, a modified cryptocrystalline flake, two wood fragments (likely not cultural remains), and a possible basalt flake. 
A 13-centimeter diameter auger probe hole was placed in the northeast corner of the excavation unit to determine if cultural material or intact sediments were present below excavation level 13. This probe was discontinued when it became apparent that the gravel and cobble sediments below excavation level 13 could not be breached with the auger.

\subsection{Discussion of Sediments at Well 199-K-131}

Three specific strata were observed during the course of the excavation. See Figure 6.2 for a profile of test unit north wall, and Figure 6.3 for the photograph of the excavation wall.

- Stratum \#1: Brown/grey cobble, gravel, and sand fill; very loose; very friable; non-sticky, nonplastic; no roots, no pores; approximately $50 \%$ rounded cobble and gravel. Clear wavy boundary to stratum \#2.

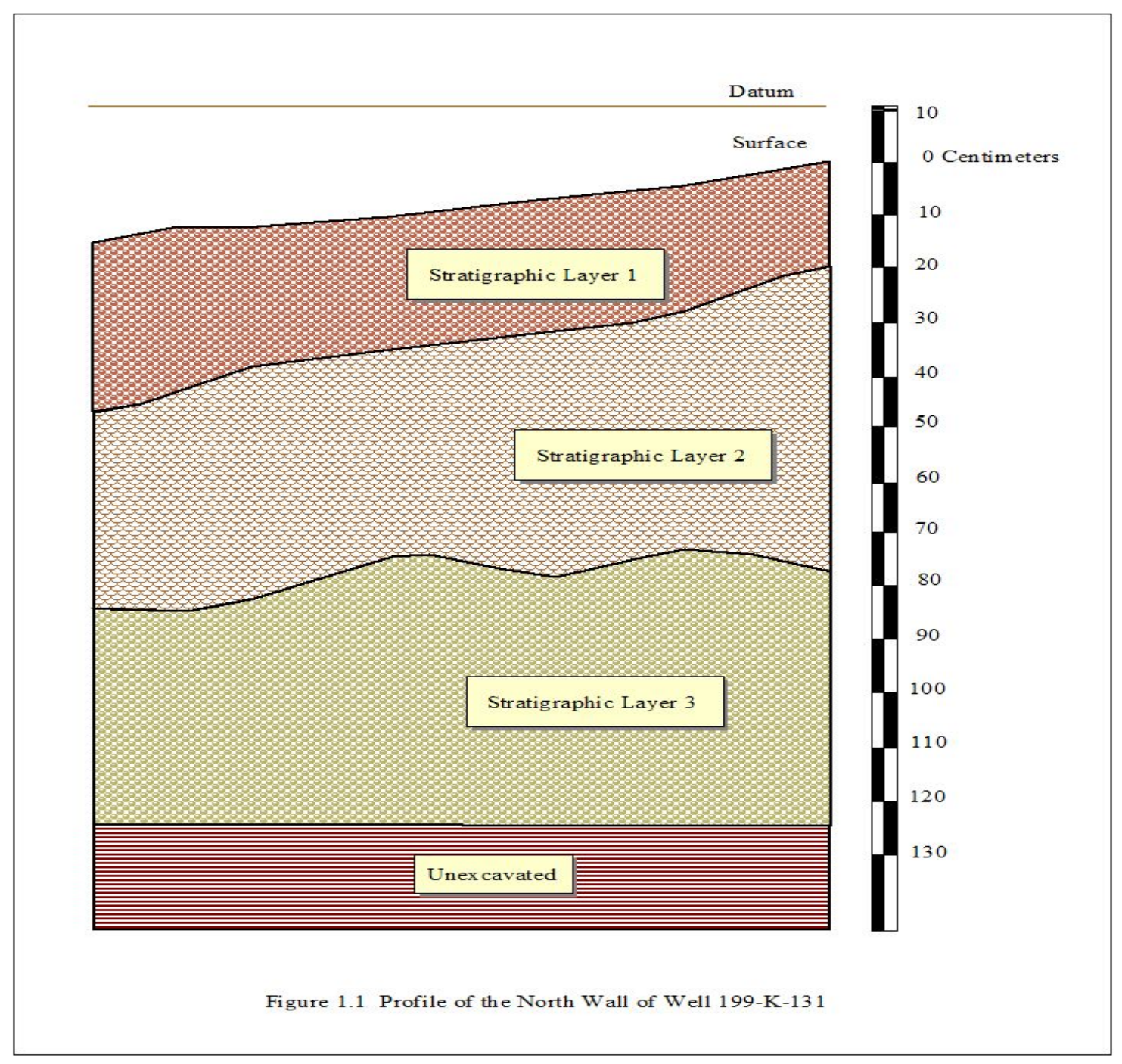

Figure 6.2. Profile of the North Wall of the 199-K-131 Excavation Unit 


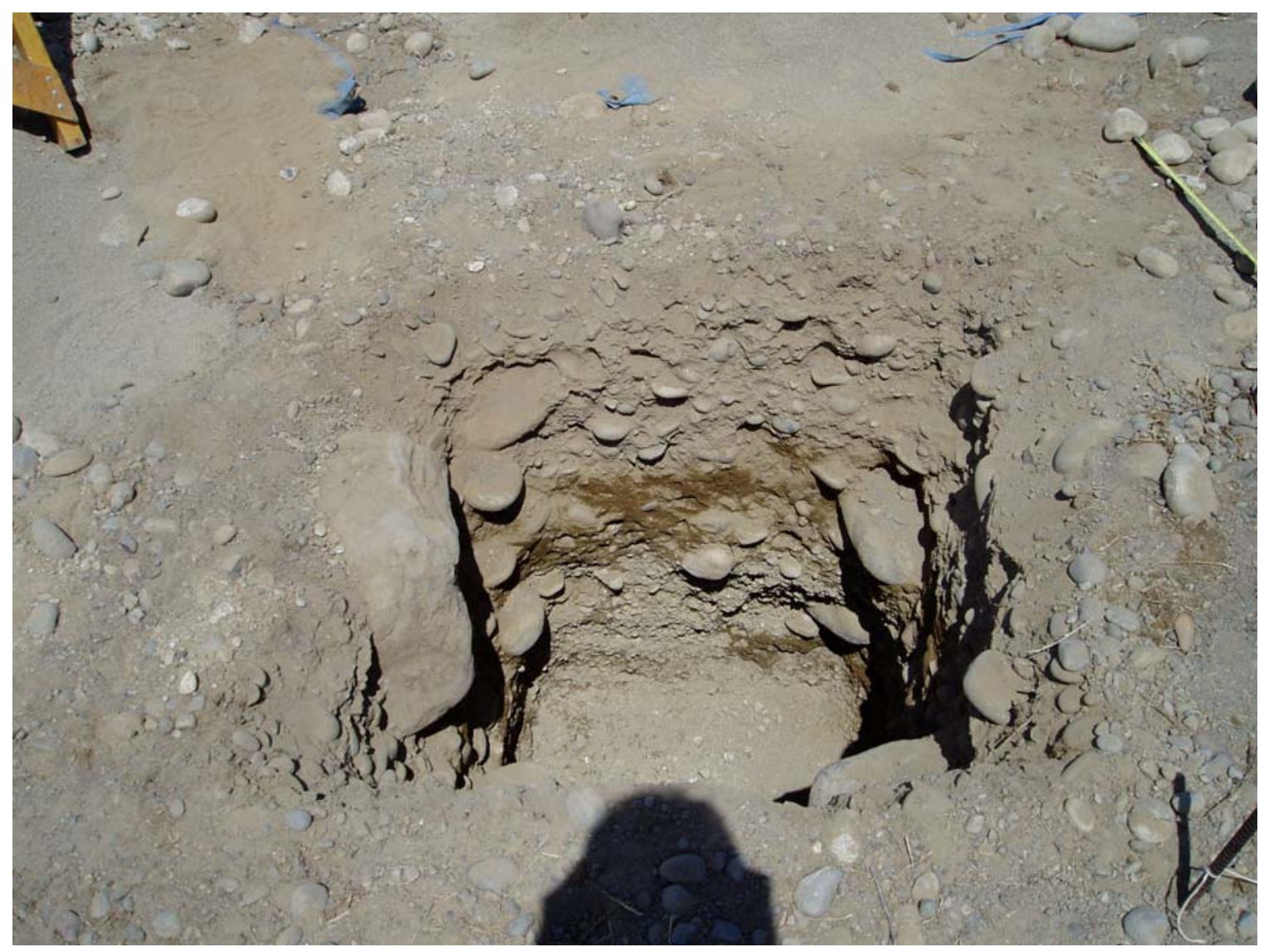

Figure 6.3. Photograph Showing the North Wall of the Excavation Unit

- Stratum \#2: Brown/grey cobble, gravel, and sand fill; very loose, very friable; non-sticky, nonplastic; many fine roots, no pores; approximately 50\%-70\% rounded cobbles and gravels. Abrupt wavy boundary to stratum \#3.

- Stratum \#3: Brown fine sands, silt, and gravel; loose, friable; non-sticky, non-plastic; many fine roots; approximately 70\%-90\% rounded gravels with occasional cobble.

The sediments encountered during the course of excavation appear to be entirely fill material. The specific and general location of proposed well 199-K-131 has been heavily impacted since the establishment of the Hanford Site and the construction of N Reactor in the 1950s. A spoils pile created by construction in the $\mathrm{N}$ Reactor area was located in the vicinity of proposed well 199-K-131. The majority of this spoils pile was cleared in early 2004, leaving behind the extensive cobble field found currently. Strata \#1 and \#2, which extended to approximately 1 meter below surface, are the subsurface remains of this spoils pile. Stratum \#3 was quite different from the overlying sediments. This stratum consists almost entirely of rounded gravels with very little cobble content. It is likely that this stratum is also fill material, possibly derived from past construction in the area, or from the road which was located adjacent to the well locale prior to the clearing of the spoils pile. Two specific factors make this likely. First, two previous excavations conducted in support of the 100-KR-4 Pump-and-Treat Project on the top of the 
terrace where 199-K-131 would be located demonstrate intact sediments comprised of approximately 40 centimeters of Holocene-aged aeolian silts overlying late-Pleistocene aged glacial-fluvial cobble deposits (Marceau and Sharpe 2001; Woody and Prendergast 2003). This sediment profile was not observed at the 199-K-131 well locale. Second, a small area of undisturbed deposits is located approximately 30 meters to the east of the $199-\mathrm{K}-131$ well locale. This area appears undisturbed due to the extensive sagebrush growth observed on the surface. Within this locale, surface sediments consist of yellow/brown fine sands and silts much like those observed on the surface at the previous Pump-andTreat excavations. These sediments were not encountered at any time during excavation at the 199-K-131 well locale.

\subsection{Discussion of Cultural Materials Observed at Well 199-K-131}

A total of three artifacts were observed during excavations at the 199-K-131 well locale: a possible basalt flake, a cryptocrystalline flake, and a modern wire nail. All materials were derived from level 5 (50 to 60 centimeters below test unit datum) of the excavation unit within the cobble fill of the former spoils pile, indicating the lack of archaeological integrity for these materials. These materials were likely derived from the original location of the spoils sediments (within the N Reactor area) and redeposited to this locale. 


\subsection{References}

Marceau TE and JJ Sharpe. 2001. Archaeological Excavation Report for Extraction Well C3662 in Support of the 100-KR-4 Pump-and-Treat Project. BHI-01645, Draft A, Bechtel Hanford, Inc, Richland, Washington.

Marceau TE and JK Woodruff. 1996. Cultural Resources Report Narrative for the 100-KR-4 Pump-andTreat System (HCRC\# 96-100-013).

Relander C. 1986. Drummers and Dreamers. Pacific Northwest National Parks and Forests Association, Seattle, Washington.

U.S. Department of Energy, Richland Operations Office (DOE-RL). 1992. Remedial Investigation/Feasibility Study Work Plan for the 100-KR-4 Operable Unit, Hanford Site, Richland, Washington. DOE/RL-90-21, Rev. 0, U.S. Department of Energy, Richland Operations Office, Richland, Washington.

U.S. Department of Energy, Richland Operations Office (DOE-RL). 1996. Treatment Plan for Protection of Cultural Resources for the 100-KR-4 Pump-and-Treat Project. DOE/RL-96-44, Rev. 0, U.S.

Department of Energy, Richland Operations Office, Richland, Washington.

Woody DM and EL Prendergast. 2003. Archaeological Excavation Report for Proposed Wells C4120 and C4117 in Support of the 100-KR-4 Pump-and-Treat Project. PNNL-14196, Pacific Northwest National Laboratory, Richland, Washington. 